\title{
Pollen: ovule ratio and its relationship with other reproductive traits in some Passiflora species (Passifloraceae)
}

\author{
María Teresa Amela García ${ }^{1 *}$, María Belén Miguez ${ }^{1} \&$ Gerhard Gottsberger $^{2}$ \\ ${ }^{1}$ DBBE, FCEyN, Universidad de Buenos Aires, Lab. 79, 4p., Pab. II, 1428 Ciudad Universitaria, C.A.B.A., Argentina \\ ${ }^{2}$ Botanical Garden and Herbarium, University of Ulm, $89081 \mathrm{Ulm}$, Germany \\ amela@bg.fcen.uba.ar; belen.miguez.10@gmail.com; gerhard.gottsberger@uni-ulm.de
}

\begin{abstract}
Amela García, M.T., Miguez, M.B. \& Gottsberger, G. 2014. Pollen: ovule ratio and its relationship with other reproductive traits in some Passiflora species (Passifloraceae). Anales Jard. Bot. Madrid 71(2): e009.

The pollen/ovule $(\mathrm{P} / \mathrm{O})$ ratio has been used as predictor of the reproductive system of angiosperms (lowest P/O values correspond to obligate autogamous species while the highest correlate with obligate xenogamous species) but it does not keep for all the taxa. The relation of P/O index with pollen and stigma size, flower diameter, pollen vitality, stigmatic area/pollen-bearing area of the pollinators ratio (SA/PBA), taxonomy and breeding system was analyzed in four Passiflora species with different degree of compatibility, pollination system and taxonomic placement. P/O of the self-compatible species (with shorter anthesis, scarce pollinator visits or minor longevity) was lower than $\mathrm{P} / \mathrm{O}$ of the selfincompatible ones. The P/O values of the outcrossers could be related with the highly efficient pollination performed by the frequently visiting Xylocopa species; these bees transport Passiflora pollen in a usually monospecific mass on the thorax, resembling grouped pollen dispersal. All the taxa exhibited pollen with unimodal size and high vitality, except for P. misera, in which pollen size was bimodal, with similar quantities of grains in both classes, the large being more vital than the small ones. Correlations of P/O were positive with flower size, negative with stigma area/pollen-bearing area of the pollinator, null with stigma area and not significant with pollen size. The P/O ratio did not reflect taxonomic affinities; this index and the breeding system were more related with pollinator type, anthesis, flower size and SA/PBA than with pollen grain or stigma size.
\end{abstract}

Keywords: pollen size, pollen vitality, breeding systems, flower size, stigma area, pollen-bearing area, pollinators, anthesis, plant longevity, sexual system.

\section{INTRODUCTION}

The widely cited paper by Cruden (1977) about the proportion of pollen/ovules $(\mathrm{P} / \mathrm{O})$ of the angiosperms as indicator of their reproductive system and the ecological successional stages they occupy $(\mathrm{P} / \mathrm{O}$ value increases with degree of xenogamy and successional stage) stimulated much subsequent research. Various authors have used the $\mathrm{P} / \mathrm{O}$ ratio directly as predictor of breeding systems (Lindsey, 1982; Ortega Olivencia \& al., 1997; López \& al., 1999); others have analyzed if the $\mathrm{P} / \mathrm{O}$ ratio coincides or not with the predictions of that foundational work (Preston, 1986; Plitmann and Levin, 1990; Spira, 1980; Wyatt, 1984; Roitman and Medán, 1994; Affre and Thompson, 1998; Weller \& al., 1998; Galloni \& al., 2007; Hokche and Ramírez, 2008). Even Cruden and McClain (1996) tested the P/O ratio in additional species.

\section{Resumen}

Amela García, M.T., Miguez, M.B. \& Gottsberger, G. 2014. El índice polen/óvulos y su relación con otros rasgos reproductivos en varias especies de Passiflora (Passifloraceae). Anales Jard. Bot. Madrid 71(2): e009.

La utilidad del índice polen/óvulos (P/O) para predecir el sistema reproductivo de las Angiospermas (los valores más bajos corresponden a especies autógamas obligadas mientras que los valores más altos a especies xenógamas obligadas) no siempre ocurre. Analizamos la relación del P/O respecto del tamaño del polen y estigma, diámetro floral, viabilidad polínica, proporción área estigmática/área de acarreo del polen por los polinizadores, la taxonomía y el sistema reproductivo en cuatro especies de Passiflora con grado de compatibilidad, polinizadores y posición taxonómica distintos. El P/O de las especies auto-compatibles (con antesis más corta, polinizadores infrecuentes o menos longevidad) fue menor que el de las auto-incompatibles. Esto estaría relacionado con la polinización altamente eficiente que realizan asiduamente Xylocopa spp., transportando polen de Passiflora en masa, usualmente monoespecífica sobre el tórax, semejando dispersión polínica agrupada. Todos los taxones exhibieron polen de tamaño unimodal y alta vitalidad, excepto $P$. misera, en que fue bimodal, con cantidades similares de granos en ambas clases, los grandes más vitales que los pequeños. La correlación del P/O fue positiva con el tamaño floral, negativa con la proporción área del estigma/área de acarreo del polen por el polinizador, nula con el área del estigma y no significativa con el tamaño del polen. El P/O no reflejó afinidades taxonómicas; este índice y el sistema reproductivo estuvieron más relacionados con el tipo de polinizador, la antesis, el tamaño floral y la razón área del estigma/área de acarreo del polen por el polinizador que con el tamaño del polen o del estigma.

Palabras clave: tamaño del polen, vitalidad del polen, sistemas reproductivos, tamaño de la flor, área estigmática, área de acarreo del polen, polinizadores, antesis, longevidad de la planta, sistema sexual.

$\mathrm{P} / \mathrm{O}$ adjustments have been probed at various levels, i.e., between populations (Wyatt, 1984) or races (Schoen, 1977) and within genera (Spira, 1980; Ortega Olivencia \& al., 1997; Affre and Thompson, 1998), tribes (Small, 1988; López \& al., 1999; Galloni \& al., 2007) and families (Preston, 1986; Plitman and Levin, 1990; Weller \& al., 1998; Wyatt \& al., 2000; Choteau \& al., 2006; Hokche and Ramírez, 2008; Devoto and Medán, 2008).

In most cases, $\mathrm{P} / \mathrm{O}$ ratio falls within the ranges calculated by Cruden (1977) or keeping the tendency (P/O of autogamous species lower than $\mathrm{P} / \mathrm{O}$ of xenogamous species) (Schoen, 1977; Spira, 1980; Wyatt, 1984; Preston, 1986; Graumann and Gottsberger, 1988; Ortega Olivencia and Devesa Alcarez, 1993; Weller \& al., 1998; Christ \& al., 2001; Lehnebach and Riveros, 2003; Medán, 2003), but some exhibit higher (Choteau \& al., 2006; Devoto and Medán, 2008; Hokche and Ramírez, 2008) or lower (Wild \& al., 
2003; Galloni \& al., 2007) values than expected. Rather than breeding system, in several taxa $\mathrm{P} / \mathrm{O}$ ratio reflects better pollination mechanism (Galloni \& al., 2007) or pollination efficiency (Choteau \& al., 2006). P/O ratio was significantly associated with pollination mechanism in species with unknown breeding system (López \& al., 1999) and in 21 xenogamous legumes (Etcheverry \& al., 2012). Lower $\mathrm{P} / \mathrm{O}$ ratios usually coincide with precise or highly specialized pollen transfer mechanisms (Small, 1988; Jürgens \& al., 2002; Choteau \& al., 2006). This has been exemplified in the Mimosoideae (Cruden, 1977). The extreme is represented in Asclepiadoidea (Cruden, 1977; Wyatt \& al., 2000). Lack of adjustment to expected values of $\mathrm{P} / \mathrm{O}$ were also discussed in relation to pollination ecology (Affre and Thompson, 1998).

Cruden (2000) admitted that this index might be confusing, especially for xenogamous species with low $\mathrm{P} / \mathrm{O}$ ratio, many of which have large pollen grains and/or large stigmas, based on the relation between $\mathrm{P} / \mathrm{O}$ ratio, pollen size and the ratio of stigma area to the pollen-bearing area of the pollinators (SA/PBA) (Cruden and Miller-Ward, 1981). The stigma area is expected to be large enough to receive sufficient pollen grains to fertilize a large number of ovules (Cruden and Miller-Ward, 1981); the SA/PBA was used as a measure of the likelihood of a pollen grain reaching a stigma, and it was hypothesized that $\mathrm{P} / \mathrm{O}$ would be inversely related to SA/PBA (Cruden and Miller-Ward, 1981).

$\mathrm{P} / \mathrm{O}$ ratio, breeding system and pollen vitality, which implies the proportion of grains capable of fertilization, have been investigated concomitantly in few studies (Lindsey, 1982; Hoc and Amela García, 1998, 1999; López \& al., 1999; Lehnebach and Riveros, 2003; Wild \& al., 2003), but pollen vitality has not been related to $\mathrm{P} / \mathrm{O}$ or breeding system.

$\mathrm{P} / \mathrm{O}$ ratio has further been explored in relation to sexual system (Lindsey, 1982; Jürgens \& al., 2002; Choteau \& al., 2006), pollination system (Plitman and Levin, 1990; Götzenberger \& al., 2008), life form (Cruden, 1977; Small, 1988; Jürgens \& al., 2002), seed mass (Götzenberger \& al., 2006) and floral size (Etcheverry \& al., 2012), among other parameters (see Ortega Olivencia \& al., 1997).

P/O ratio has not been examined in Passiflora L. yet. Preliminary records in species with known breeding system (Amela García, 1999) suggest that this index is lower than expected by the predictions of Cruden (1977). The aim of this work was to explore the relationship between $\mathrm{P} / \mathrm{O}$ ratio, pollen and stigma size, flower size, pollen vitality, pollen-bearing area and pollen transfer efficiency in Passiflora species with different degree of self-compatibility and from different infrageneric categories, to know how these floral traits interrelate and corroborate if the $\mathrm{P} / \mathrm{O}$ ratio predicts the breeding system or reflects taxonomic affinities in Passiflora.

\section{MATERIAL AND METHODS}

\section{Plantmaterial}

Samples of the following species were obtained at the following respective sites in Argentina: P. caerulea (Merlo, Buenos Aires province), P. foetida (Charata, Chaco province), P. suberosa (San José, Misiones province), P. misera (Iguazú National Park, Misiones province). The first two taxa are included in subgenus Passiflora while the last two belong to subgenus Decaloba (Feuillet \& MacDougal, 2004).
Buds ready to open were collected and fixed in ethanol $70^{\circ}$ for pollen and ovule counts, pollen and stigma size measurements, whereas other buds were dried between paper sheets for pollen vitality tests.

\section{Pollen and ovule counts}

For pollen grain number estimation, anthers were opened under a dissecting microscope and all the pollen was transferred to plastic tubes containing $5 \mathrm{ml}$ of $0.9 \% \mathrm{NaCl}$ solution. Pollen grains were counted with a cell counter and analyzer system CASY (Schärfe System, Reutlingen, Germany). The number obtained was multiplied by the number of anthers of the bud. The ovules were counted dissecting the ovary under a stereoscopic microscope. The $\mathrm{P} / \mathrm{O}$ index (ratio between pollen grains and ovules of a bud) defined by Cruden (1977) was calculated, the values obtained were compared with the ranges given by that author and with the breeding system, which had been determined with controlled pollinations (Amela García, 1999).

\section{Pollen size and vitality}

The pollen grain size was measured with the automatic cell counter and analyzer system mentioned above. This device gives the diameter of the figure according to the position it is, so it is somewhat like an average between the equatorial and polar axis in these subespheroidal grains (Amela García $\&$ al., 2002). Pollen vitality was estimated by optical contrastfluorescence microscopy (Greissl, 1989) and by staining the main pollen constituents, lipids in all of them (Amela García, 1999), with Sudan IV (Kerns and Inouye, 1993).

\section{Stigma area and pollen-bearing area of the pollinators}

Passiflora species have capitate stigmas, whose most resembling geometric form is an ellipse, so the longer and the shorter axis were measured with an ocular micrometer of a dissecting microscope, converted to $\mathrm{mm}$ and then the ellipse area was calculated. The deposition site of the pollen of Passiflora species on their pollinators is the thorax dorsum, which can be resembled to a rectangle, so the length and the width were measured and then the rectangle area was calculated. Dimensions were taken at naked eye with a ruler made of graph paper, on specimens deposited at the Museo Argentino de Ciencias Naturales "B. Rivadavia". Pollinators were chosen based on previous works (Amela García, 1999; Amela García and Hoc, 1997, 1998a, 2001). Specimens of the pollinators of $P$. suberosa could not be measured as they were not available for us. Afterwards, the stigma area/pollen bearing area was calculated for each species.

\section{Flower size}

The major diameter (distance between the apexes of opposite sepals) was measured on fresh material with graph paper at naked eye in these actinomorphic flowers.

\section{Statistical analysis}

The data were subjected to ANOVA and correlation analysis using the statistical program InfoStat 9.0 (2009). 


\section{RESULTS}

\section{$P / O$ ratio and breeding system}

$\mathrm{P} / \mathrm{O}$ ratios differed significantly between the selfincompatible and the self-compatible species: $F=50.66$, $\mathrm{p}<0.0001, \mathrm{n}=89$ (Table 1); P/O of self-incompatible species were higher ( 3 folds) than those of the self-compatible ones.

\section{Pollen grain size and vitality}

The pollen grain size was rather constant within each species, considering the little standard deviation (Table 2) and differed significantly between some species $(F=308.11$, $\mathrm{p}<0.0001, \mathrm{n}=94$ ) (Table 2); P. misera exhibited greater variation, in this species a tendency to a bimodal distribution was detected (Fig. 1). Pollen vitality was high in all species with both tested staining methods (Table 3); in $P$. misera, vitality was notoriously higher in the bigger grains (Table 3).

\section{$P / O$, pollen grain size, flower size, stigma area and $S A / P B A$}

The correlation between $\mathrm{P} / \mathrm{O}$ and pollen grain size was not significant (Fig. 2A).

Flower size (Table 2 ) varied significantly between some species $(F=109.97, \mathrm{p}<0.0001, \mathrm{n}=47)$ and was positively correlated with $\mathrm{P} / \mathrm{O}$ (Fig. 2B).

The stigmatic area differed significantly between some species $(F=27.918, \mathrm{p}=0, \mathrm{n}=62$; Table 4$)$. The $\mathrm{P} / \mathrm{O}$ index was not correlated with stigma area (Fig. 2C) but it was inversely and strongly $(-167.40)$ correlated with the SA/ PBA (r=0.418, p=0.0002, n=73) (Fig. 3).

\section{DISCUSSION}

\section{$P / O$, breeding system, pollinators, anthesis and plant longevity}

The lower $\mathrm{P} / \mathrm{O}$ ratios of $P$. foetida and P. suberosa as compared to the ones of $P$. caerulea and $P$. misera are in accordance with the self-compatibility of the former and the self-incompatibility of the latter (Amela García, 1999), and the tendency coincides with the one discovered by Cruden (1977). Nevertheless, P/O values were lower than expected by the predictions of Cruden (1977) for all the species, irrespective of their breeding system; however, $\mathrm{P} / \mathrm{O}$ of selfcompatible species resulted more closely to Cruden's values, but the ones of xenogamous species were substantially lower than those proposed by him. Based on the ranges given for xenogamous taxa, Cruden and Miller-Ward (1981) argued that species with very efficient pollen transfer mechanisms had lower $\mathrm{P} / \mathrm{O}$ ratios than expected as compared to species with equivalent breeding systems but less efficient pollen flow. The specialization between bees and flowers results in a more efficient pollination with less pollen loss (Pijl, 1954). Probably the low $\mathrm{P} / \mathrm{O}$ ratio in $P$. caerulea and P. misera is related with the efficient pollen transfer performed by Xylocopa species (Amela García and Hoc, 1997 and Amela García unpublished. data, respectively), becoming unnecessary a major pollen production. Their reproductive system could be assimilated to the one of "sweepstakes" (Cruden, 1977), as, although pollen is not clustered by abundant pollenkit or viscin threads nor grouped in pollinia, the transport in mass on the pollinators thorax, comprising the majority or even the whole pollen load in this body part, would be comparable with those agglutinations. Every time a pollinator visits a flower it takes a considerable amount of grains

Table 1. Breeding system (determined by experimental pollinations), pollen and ovule number, P/O ratio and estimated breeding system by P/O ratio of four Passiflora species

\begin{tabular}{lcccc}
\hline Species & P. foetida & P. caerulea & P. misera & P. suberosa \\
\hline Breeding system & psc & si & si & hsc \\
Pollen & $6,667 \pm 1,241$ & $164,216 \pm 43,537$ & $23,873 \pm 6,145$ & $6,319 \pm 4,342$ \\
& $26(14)$ & $26(10)$ & $25(3)$ & $14(3)$ \\
Ovules & $31 \pm 4$ & $252 \pm 45$ & $41 \pm 8$ & $24 \pm 2$ \\
& $26(14)$ & $25(10)$ & $24(3)$ & $14(3)$ \\
P/O & $216.62^{\mathrm{a}} \pm 40.39$ & $656.67^{\mathrm{b}} \pm 141.73$ & $601.44^{\mathrm{b}} \pm 209.74$ & $262.26^{\mathrm{a}} \pm 183.59$ \\
& $26(14)$ & $25(10)$ & $24(3)$ & $14(3)$ \\
Estimated breeding system & $\mathrm{fa}$ & $\mathrm{fa}-\mathrm{fx}$ & $\mathrm{fx}$ & $\mathrm{fa}$ \\
\hline
\end{tabular}

Numbers within each cell represent: average \pm standard deviation and $n=$ number of flowers (plants); si=self-incompatible; $\mathrm{psc}=$ partially self-compatible; $\mathrm{hsc}=$ highly self-compatible; $\mathrm{fa}=\mathrm{facultative}$ autogamous; $\mathrm{fx}=\mathrm{facultative}$ xenogamous. Values with different letters differed significantly at $p<0.0001$.

Table 2. Pollen grain size and flower size of four Passiflora species

\begin{tabular}{lcccc}
\hline Species & P. foetida & P. caerulea & P. misera & P. suberosa \\
\hline Pollen diameter $(\mu \mathrm{m})$ & $63.39^{\mathrm{a}} \pm 1.46$ & $59.56^{\mathrm{a}} \pm 1.26$ & $38.28^{\mathrm{b}} \pm 6.02$ & $43.45^{\mathrm{c}} \pm 1.79$ \\
& $44(13)$ & $10(2)$ & $32(1)$ & $8(1)$ \\
Flower size $(\mathrm{mm})$ & $41.44^{\mathrm{a}} \pm 3.05$ & $40.73^{\mathrm{a}} \pm 8.68$ & $27.4^{\mathrm{b}} \pm 3.5$ & $9^{\mathrm{c}} \pm 0.85$ \\
& $9(9)$ & $11(11)$ & $15(5)$ & $12(12)$ \\
\hline
\end{tabular}

Values with different letters differ significantly at $p<0.01$. Numbers within each cell represent the average \pm standard deviation and $n=$ number of anthers or flowers (number of plants). 
A
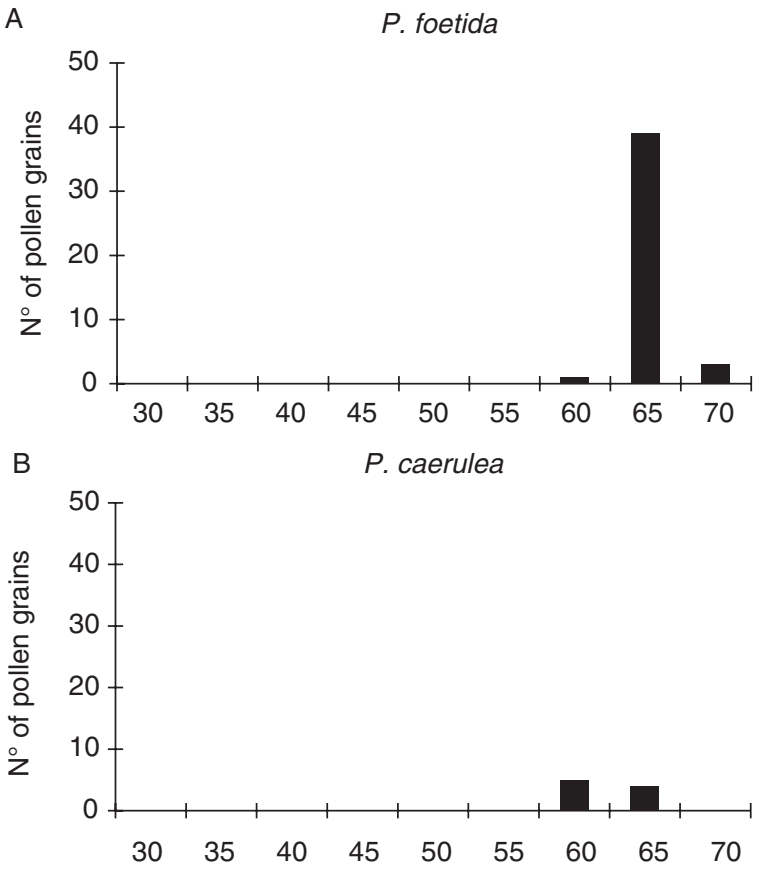

C
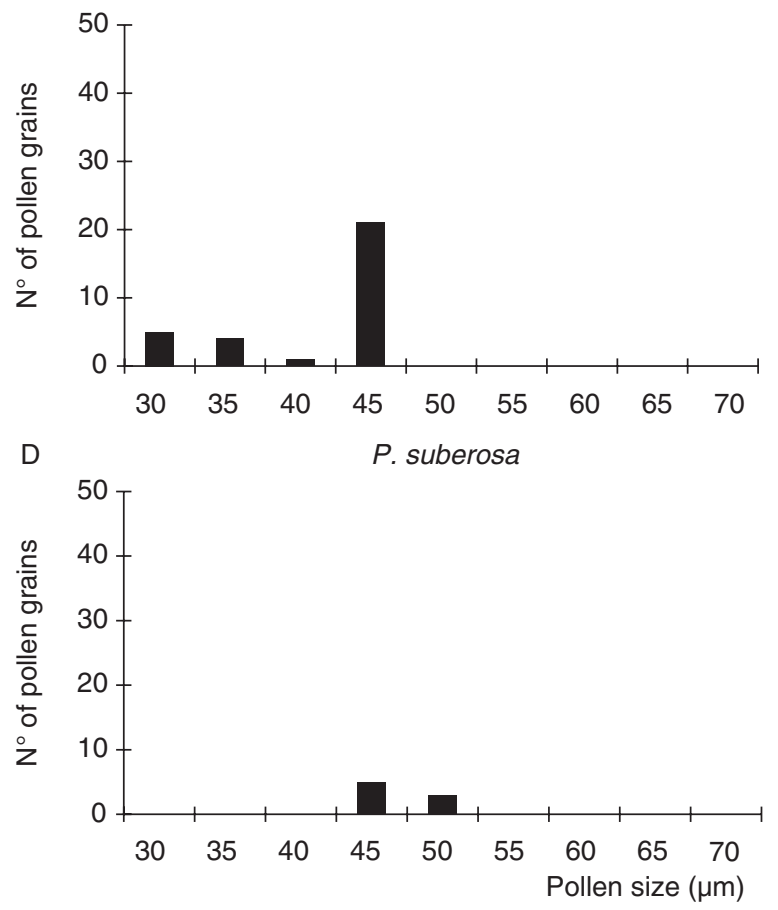

Fig. 1. Frequency distribution of pollen grains in pollen size classes of four Passiflora species.

Table 3. Pollen vitality of four Passiflora species with two different techniques: fluorescence and main constituents

\begin{tabular}{lcccc}
\hline Species & P. foetida & P. caerulea & P. misera & P. misera \\
\hline fluorescence \% (n) & $90(100)$ & $86(89)$ & I: $100(164)$ & $82(206)$ \\
& & & s: $4(160)$ & \\
constituents \% (n) & $98(363)$ & $96(307)$ & - & $96(644)$
\end{tabular}

$\mathrm{n}=$ number of pollen grains tested; I=large grains; s=small grains .
A

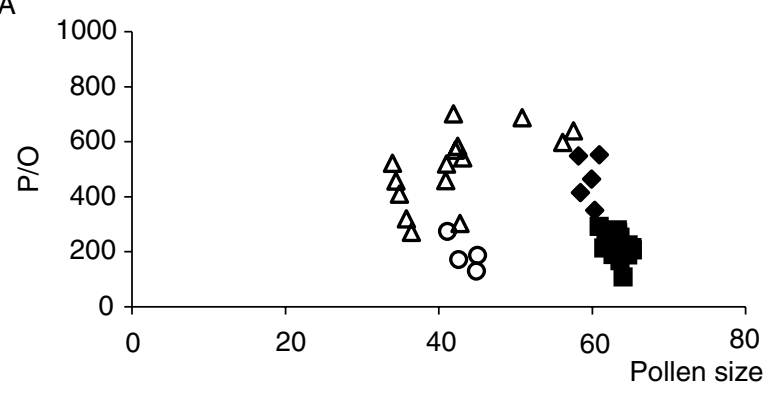

B
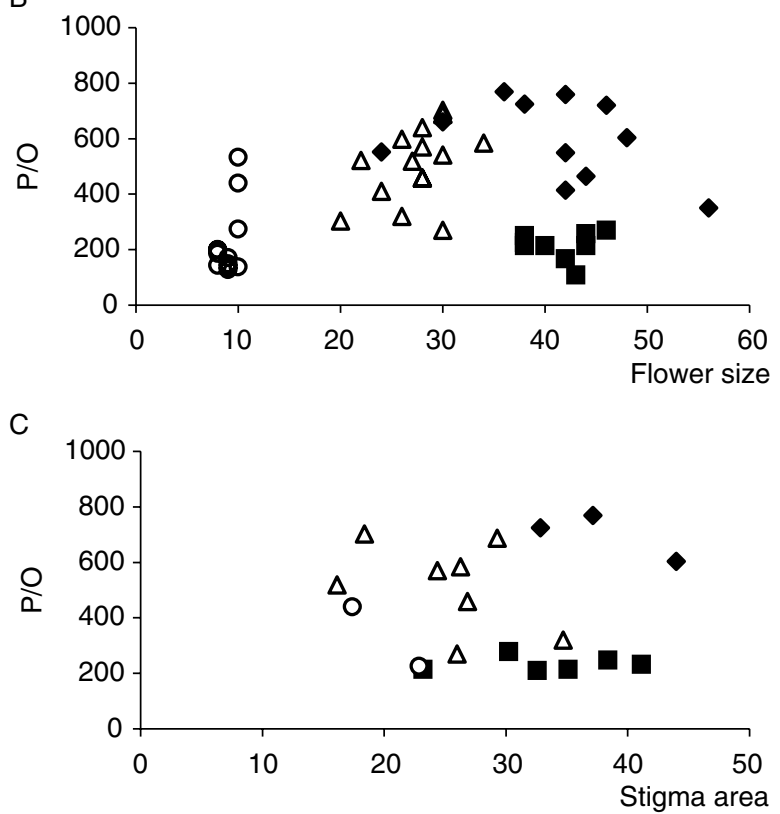

Fig. 2. Relationship between pollen/ovule ratio $(P / O)$ and other floral traits of four Passiflora species. $\boldsymbol{\square}=P$. foetida, $\bullet=P$. caerulea, $\triangle=P$. misera, $\mathrm{O}=\mathrm{P}$. suberosa.

from the anthers (usually getting most of the notothorax covered with pollen), and leaves a similar quantity of pollen through its wide contact with the stigmas when they are deflected. Cruden and Miller-Ward (1981) found that P/O was negatively correlated with the pollen-bearing area of the pollinators and with pollen grain size. An additional coincidence with these authors' observations is that most of the xenogamous species with the lower $\mathrm{P} / \mathrm{O}$ ratio have larger pollen grains: P. caerulea (this work) and P. mooreana (Amela García and Hoc, 1998b).

Still, P/O ratios of self-compatible species were a bit lower than expectations of Cruden (1977). An inverse relation between $\mathrm{P} / \mathrm{O}$ ratio and pollinator reliability was anticipated by Cruden and Miller-Ward (1981) but low P/O ratio of a self-compatible orchid also coincided with low pollinator visitation rate (Lehnebach and Riveros, 2003). Pollinator constancy of P. foetida is high (Amela García and Hoc, 1998a). In contrast, scarce frequency of pollinators to $P$. suberosa might be compensated by its longer anthesis and its higher degree of self-compatibility (Amela García, 2008) as compared to P. foetida (Amela García and Hoc, 1997). In all the Passiflora species studied so far, stigma receptivity lasts the whole anthesis (Amela García, 1999), so anthesis 
Table 4. Stigma area of four Passiflora species, thorax area of their pollinators and stigma area/pollen-bearing area (SA/PBA)

\begin{tabular}{|c|c|c|c|c|}
\hline Species & stigma area & pollinator & thorax area & SA/PBA \\
\hline \multirow[t]{4}{*}{ P. caerulea } & \multirow{4}{*}{$\begin{array}{c}46.15^{b} \pm 12.56 \\
n=24\end{array}$} & Xylocopa frontalis & $\begin{array}{c}101.9 \pm 18.57 \\
n=10\end{array}$ & $0.43 \pm 0.12$ \\
\hline & & Xylocopa artifex & $\begin{array}{c}43.7 \pm 7.41 \\
n=10\end{array}$ & $1.03 \pm 0.35$ \\
\hline & & Xylocopa nigrocincta & $\begin{array}{c}87.8 \pm 11.14 \\
n=10\end{array}$ & $0.49 \pm 0.08$ \\
\hline & & Xylocopa augusti & $\begin{array}{c}84.6 \pm 13.35 \\
n=10\end{array}$ & $0.53 \pm 0.17$ \\
\hline \multirow[t]{3}{*}{ P. foetida } & \multirow{3}{*}{$\begin{array}{c}32.45^{\mathrm{a}} \pm 7.48 \\
n=10\end{array}$} & Ptiloglossa tarsata (male) & $\begin{array}{c}116.4 \pm 9.15 \\
n=10\end{array}$ & $0.58 \pm 0.20$ \\
\hline & & Ptiloglossa tarsata (female) & $\begin{array}{c}43.1 \pm 11.25 \\
n=10\end{array}$ & $0.77 \pm 0.18$ \\
\hline & & Pseudaugochloropsis graminea & $\begin{array}{c}12.5 \pm 2.12 \\
n=10\end{array}$ & $2.69 \pm 0.99$ \\
\hline \multirow[t]{2}{*}{ P. misera } & \multirow{2}{*}{$\begin{array}{c}26.26^{\mathrm{a}} \pm 5.86 \\
n=10\end{array}$} & Ptiloglossa sp. & $\begin{array}{r}42 \pm 0 \\
n=2\end{array}$ & $0.64 \pm 0$ \\
\hline & & Xylocopa artifex & $\begin{array}{c}43.7 \pm 7.41 \\
n=10\end{array}$ & $0.62 \pm 0.21$ \\
\hline P. suberosa & $\begin{array}{c}21.28^{\mathrm{a}} \pm 5.14 \\
\mathrm{n}=18\end{array}$ & -------- & -------- & -------- \\
\hline
\end{tabular}

Numbers within each cell represent averages \pm standard deviation and $n=$ number of measured specimens. Dimensions are in $\mathrm{mm}$. Values with different letters differ significantly at $p<0.01$.

duration is a direct indicator of receptivity in them. A positive relation between $\mathrm{P} / \mathrm{O}$ ratio, degree of outcrossing and flower life span occurred between different populations analyzed by Wyatt (1984) and species analyzed by Choteau \& al (2006). A tendency in these traits may be seen in the Passiflora species analyzed: anthesis duration of $P$. foetida $<P$. suberosa similar to $P$. misera $<$ P. caerulea.

Among the vines studied, there is also a trend between degree of self-compatibility, $\mathrm{P} / \mathrm{O}$ and longevity. The selfcompatible species, with lower $\mathrm{P} / \mathrm{O}$ ratio, are annuals (the whole plant or the aerial stems) or biannuals (except from P. suberosa, that lives longer) whilst the self-incompatible ones, with higher $\mathrm{P} / \mathrm{O}$ ratio, render successfully more years. This tendency, discovered by Cruden (1977), was further confirmed in various taxa (Small, 1988; Plitman and Levin,
1990; Galloni \& al., 2000; Jürgens \& al., 2002; Choteau $\&$ al., 2006) with isolated exceptions (López \& al., 1999).

\section{$P / O$, pollen grain size, pollen vitality and breeding system}

Although the pollen grains of the examined Passiflora species were large (P. foetida and P. caerulea) or mediumsized ( $P$. misera and $P$. suberosa), considering the categories established by Erdtman (1952), no significant correlation was found between $\mathrm{P} / \mathrm{O}$ and pollen grain size, in contrast to predictions by Cruden \& Miller-Ward (1981). This relation varies among taxa: positive but weak for Asclepiadaceae (Wyatt, 1984), null for Genisteae (López \& al., 1999) and negative for other taxa (Cruden and Miller-Ward, 1981; Wyatt, 1984; Cruden, 2000). Götzenberger \& al. (2007)

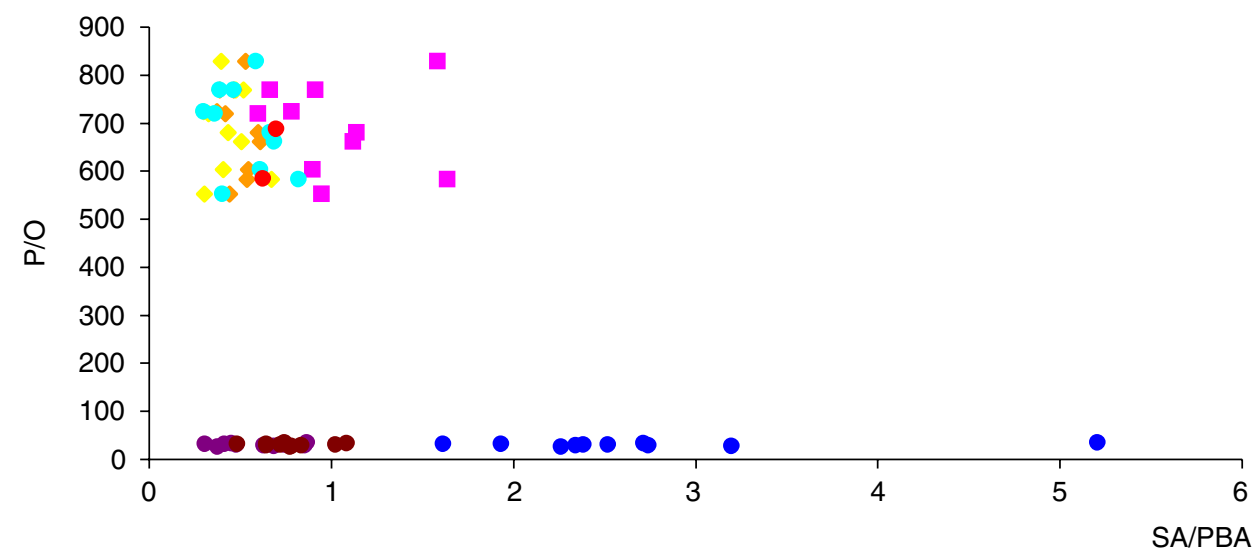

Fig. 3. Relationship between pollen/ovule (P/O) and stigma area/pollen-bearing area of the pollinators (SA/PBA) of four Passiflora species. Symbols: yellow=Xylocopa frontalis, pink=Xylocopa artifex, orange=Xylocopa nigrocincta, light blue=Xylocopa augusti, violet=Ptiloglossa tarsata (male), brown=Ptiloglossa tarsata (female), red=Ptiloglossa sp., blue=Pseudaugochloropsis graminea. 
concluded from 311 angiosperms that $\mathrm{P} / \mathrm{O}$ depends on pollen grain number but not size. In Passiflora, pollen grain size is related with taxonomic position (Amela García \& al., 2002) rather than with breeding system.

As in P. misera, more than one pollen grain size classes were encountered in the same anther of several Caryophylloideae but, unlike Passiflora, number of grains in each size class was dissimilar (Jürgens \& al., 2012). A bimodal pollen size distribution with the larger grains viable and the smaller ones aborted was also detected in a conifer (Aizen and Rovere, 1995). In the species with two pollen size classes, in which the smaller ones are not vital, the useful $\mathrm{P} / \mathrm{O}$ ratio would be minor than the estimated one, nearly the half in the examined Passiflora species. So pollen vitality, i.e., proportion of pollen grains capable of germination, should be taken in account in pollen or $\mathrm{P} / \mathrm{O}$ counts.

All the Passiflora species studied exhibited high pollen vitality, regardless of their breeding system. Relatively high degrees of pollen vitality have been detected for selfincompatible species (Wild \& al., 2003; Hoc and Amela García, 1998) as well as self-compatible ones (Hoc and Amela García, 1999; Lehnebach and Riveros, 2003). Low levels of pollen vitality occur in species with different degrees of inbreeding and similar pollen longevities were found in two out of four Cyclamen species with the most opposite levels of inbreeding (Affre and Thompson, 1998). So pollen vitality seems to have no relation with breeding system.

In any case, the high pollen vitality suggests that the majority of the grains would be able to fertilize the conspecific ovules, and, as the transfer is directional (by means of constant visitors), a great part of the grains would reach their destiny. Besides, in P. caerulea, vitality is not affected by rain (Amela García and Hoc, 1997), as in well protected anthers (Hoc and Amela García, 1999) but not in very exposed ones (Hoc \& al., 1995). In addition, the high vitality benefits the pollinators that feed their larvae with pollen, most Passiflora spp. pollinators carried Passiflora pollen in their hind legs (Amela García, 1999), being profitable the major part of the pollen load. In the species with large vital grains and small non vital ones, there would be a tendency to diminish the energetic cost of the pollen loss that the hymenopterans use for nesting, offering a certain non vital quantity; but that kind of grains also can reach the stigmas, as they are in the same anthers as the big ones, so this strategy would be inefficient.

\section{$P / O$, flower size, stigma area and $S A / P B A$}

The positive correlation between flower size with $\mathrm{P} / \mathrm{O}$ was also found in 14 Vicia spp. (Ortega-Olivencia \& al., 1997) but not in 21 papilionoid legumes (Etcheverry \& al., 2012).P/O ratio was not correlated with stigma area in the Passiflora species analysed, perhaps because stigma area was not so different between them. On the contrary, $\mathrm{P} / \mathrm{O}$ ratio was inversely related to the stigmatic area in two species of Stylidaceae and eight species from three genera of Proteaceae (Cruden, 1997). In the last ones, taxa with higher $\mathrm{P} / \mathrm{O}$ produced larger number of smaller pollen grains and had smaller stigmas (Cruden, 1997). The co-occurrence of large stigmas with many ovules was corroborated in several species (Cruden and Miller-Ward, 1981).
In spite of the different degree of autogamy of the studied species and the minor than expected $\mathrm{P} / \mathrm{O}$ ratio in the self-incompatible and with more efficient pollination ones, $\mathrm{P} / \mathrm{O}$ index was inversely and strongly related with the SA/PBA, as in the 19 xenogamous angiosperms studied by Cruden and Miller-Ward (1981). It is interesting to note that the pollinators that do not always pollinate, due to their behavior on the flowers, i.e., $X$. artifex in $P$. caerulea and Pseudaugochloropsis graminea in P. foetida (Amela García and Hoc, 1997 and 1998a, respectively), have smaller pollen-bearing areas and, in consequence, a major SA/PBA resulted, i.e., a lower probability of pollination.

\section{$P / O$ and sexual system}

Hermaphroditic species exhibit lower $\mathrm{P} / \mathrm{O}$ ratios and larger pollen grains than sexually dimorphic congeners (Weller \& al., 1998); lower P/O ratios have been computed for more than a hundred hermaphroditic taxa as compared to those with other sexual systems (see Cruden, 2000, Fig. 4). Having this in mind, the hermaphroditic flowers of Passiflora would be expected to have low $\mathrm{P} / \mathrm{O}$ ratios; however, other factor needs to be considered: a certain proportion of the flowers of at least 13 Passiflora spp. do not bend the styles during anthesis, thus the stigmas do not get in contact with the pollen (either of the same flower or carried by a pollinator), turning the sexual system functionally andromonoecious (Amela García and Hoc, 2011 and cites therein). Considering this sexual system, the $\mathrm{P} / \mathrm{O}$ ratio would be greater, as pollen grain number varies as a function of the percentage of male flowers (Cruden, 2000), either they are morphologically or functionally staminate. $\mathrm{P} / \mathrm{O}$ from andromonoecious species are greater than from homoecious ones (Cruden, 2000).

\section{$P / O$ and taxonomy}

The $\mathrm{P} / \mathrm{O}$ index was lower than expected in $P$. caerulea and $P$. misera whereas it approached the expected values for $P$. foetida and $P$. suberosa, so the $\mathrm{P} / \mathrm{O}$ index did not reflect taxonomic affinities in the species analysed. Wyatt \& al (2000) concluded that pollen grain and ovule number did not reflect taxonomy but ecogeographical pressures in 38 species from 4 tribes of Asclepiadoidea. Lack of consistency between phylogenetic relationships and $\mathrm{P} / \mathrm{O}$ was also detected by Mione and Anderson (1979) cited in Cruden (2000) and Affre and Thompson (1998), who found P/O more related with ecology. Instead, a tendency to xenogamy or autogamy within various taxa at different levels (genus or tribe) of Polemoniaceae (in which $\mathrm{P} / \mathrm{O}$ ratio is a good predictor of the breeding system) was perceived by Plitmann and Levin (1990). P/O variations were associated to genus but not to tribe in 21 papilionoid Legumes (Etcheverry \& al., 2012). Jürgens \& al (2002) suggested that taxonomy is indirectly related with $\mathrm{P} / \mathrm{O}$ as a consequence of the combination of features typical of each taxonomic group. $\mathrm{P} / \mathrm{O}$, like other traits related to pollination, are open to selection; as random evolution also takes part in phylogeny, $\mathrm{P} / \mathrm{O}$ could not necessarily reflect taxonomic affinities, as suggested by Affre and Thompson (1998) and Galloni \& al. (2007). 


\section{ACKNOWLEDGEMENTS}

We thank A. Roig Alsina, who kindly provided some of the bee specimens for measuring and who performed the taxonomic determinations, and $\mathrm{H}$. Teichert and $\mathrm{H}$. Malchus for pollen grains countings and measurements. This work was financed with the grants PICT 32866 of the ANPCyT (Agencia Nacional de Promoción Científica y Tecnológica) and UBACyT X100 and X823 of the UBA (Universidad de Buenos Aires) from Argentina. M.T. Amela García is a researcher from CONICET (Consejo Nacional de Investigaciones Científicas y Técnicas),

\section{REFERENCES}

Affre, L. \& Thompson, J.D. 1998. Floral trait variation in four Cyclamen (Primulaceae) species. Plant Systematics and Evolution 212: 279-293. http://dx.doi.org/10.1007/BF01089743

Aizen, M.A. \& Rovere, A.E. 1995. Does pollen viability decrease with aging? A cross-population examination in Austrocedrus chilensis (Cupressaceae). International Journal of Plant Sciences 156: 227-231. http://dx.doi.org/10.1086/297244

Amela García, M.T. 1999. Biología floral y sistema reproductivo de especies nativas de Passiflora (Passifloraceae) de la Argentina. Ph. D. Dissertation, Universidad de Buenos Aires.

Amela García, M.T. 2008. Breeding system and related floral features of Passiflora suberosa (Passifloraceae) under natural and experimental conditions in Argentina. Boletín de la Sociedad Argentina de Botánica 43: 83-93.

Amela García, M.T. \& Hoc P.S. 1997. Floral biology and reproductive system of Passiflora caerulea (Passifloraceae). Beitrage zur Biologie der Pflanzen 70: 1-20.

Amela García, M.T. \& Hoc P.S. 1998a. Biología floral de Passiflora foetida (Passifloraceae). Revista de Biología Tropical 46: 9-20.

Amela García, M.T. \& Hoc P.S. 1998b. Aspectos de la biología floral y el sistema reproductivo de Passiflora mooreana (Passifloraceae). Darwiniana 35: 9-27.

Amela García M.T. \& Hoc P.S. 2001. Pollination of Passiflora: do different pollinators serve species belonging to different subgenera? Acta Horticulturae 561: 71-74

Amela García, M.T. \& Hoc, P.S. 2011. Pollination mechanisms in Passiflora species: the common and the rare flowers. Ecological aspects and implications for horticulture. In: Raskin, N.D., Vuturro, P. T. (eds.), Pollination: Mechanisms, Ecology and Agricultural Advances: 33-55. Nova Science Publishers. New York.

Amela García, M.T., Galati, B.G. \& Anton, A.M.R. 2002. Microsporogenesis, microgametogenesis and pollen morphology of Passiflora spp. (Passifloraceae). Botanical Journal of the Linnean Society 139: 383-394. http://dx.doi.org/10.1046/j.1095-8339.2002.00072.x

Chouteau, M., Barabé, D. \& Gibernau, M. 2006. Pollen-ovule ratios in some Neotropical Araceae and their putative significance. Plant Systematics and Evolution 257: 147-157. http://dx.doi.org/10.1007/ s00606-005-0328-2

Christ, K.D., Dieterle, A. \& Gottsberger, G. 2001. Pollinators, pollen ovule ratio and the extent of cross- versus self-fertilization in the groundlayer of a spring wildflower community in a Central European forest. Phytomorphology 51: 529-540.

Cruden, R.W. 1977. Pollen-ovule ratios: a conservative indicator of breeding systems in flowering plants. Evolution: 31: 32-46. http:// dx.doi.org/10.2307/2407542

Cruden, R.W. 1997. Implications of evolutionary theory to applied pollination ecology. Acta Horticulturae 437: 27-51.

Cruden, R.W. 2000. Pollen grains: why so many? Plant Systematics and Evolution 222: 143-165. http://dx.doi.org/10.1007/BF00984100

Cruden, R W. \& Miller-Ward, S. 1981. Pollen-ovule ratio, pollen size, and the ratio of stigmatic area to the pollen-bearing area of the pollinator: an hypothesis. Evolution 35: 964-974. http://dx.doi.org/10.2307/2407867

Devoto, M. \& Medán, D. 2008. Expected mating system, floral diversity and flower visitors of five species of Iridaceae of the Argentine pampas. Acta Botanica Venezuelica 31: 425-434.

Erdtman, G. 1952. Pollen morphology and plant taxonomy. Angiosperms. The Chronica Botanica Co. Waltham. Mass.

Etcheverry, A.V., Alemán, M.M., Figueroa-Fleming, T., López-Spahr, D., Gómez, C.A., Yáñez, C., Figueroa-Castro, D.M. \& Ortega-Baes, P. 2012. Pollen:ovule ratio and its relationship with other floral traits in Papilionoidea (Leguminosae): an evaluation with Argentine species. Plant Biology 14: 171-178. http://dx.doi.org/10.1111/j.1438-8677.2011.00489.x
Feuillet, C. \& MacDougal, J.M. 2004. Systematics. In: Ulmer, T., MacDougal, J.M. (eds.), Passiflora. Passionflowers of the World. 27-31. Timber Press. Cambridge.

Galloni, M., Podda, L., Vivarelli, D. \& Cristofolini, G. 2007. Pollen presentation, pollen-ovule ratios, and other reproductive traits in Mediterranean legumes (Fabaceae- Faboideae). Plant Systematics and Evolution 266: 147-164. http://dx.doi.org/10.1007/s00606-007-0526-1

Götzenberger, L., Durka, W., Kühn, I. \& Klotz, S. 2006. The relationship between the pollen-ovule ratio and seed size: a comparative test of a sex allocation hypothesis. Evolutionary Ecology Research 8: 1101-1116.

Götzenberger, L., Durka, W., Kühn, I., Klotz, S. 2007. The relationship between pollen size and the pollen-ovule ratio. Another comparative test of sex allocation theory. Evolutionary Ecology Research 9: 1145-1161.

Götzenberger, L., Kühn, I., Klotz S. (2008) Effects of habitat disturbance and pollination type on the interspecific variation in pollen-ovule ratios. Preslia 80: 423-437.

Graumann, S. \& Gottsberger, G. 1988. Reproductive strategies in allogamous and autogamous Senecio species. Lagascalia 15: 673-679.

Greissl, R. 1989. Vitality analysis of monadic and polyadic pollen grains using optical contrast-fluorescent microscopy. Scientific and Technical Informations 15: 180-184.

Hoc, P.S. \& Amela García, M.T. 1998. Floral biology and reproductive system of Phaseolus augusti (Fabaceae). Beitrage zur Biologie der Pflanzen 70: 121-140.

Hoc, P.S. \& Amela García, M.T. 1999. Biología floral y sistema reproductivo de Phaseolus vulgaris var. aborigineus (Fabaceae). Revista Biología Tropical 47: 59-67.

Hoc, P. S., Amela García, M.T. \& Palacios, R.A. 1995. Functional andromonoecy in Prosopis alba (Mimosaceae). The effect of abiotic and biotic factors on the reproductive system. Beitrage zur Biologie der Pflanzen 69: 191-218.

Hokche, D.O. \& Ramírez, N. 2008. Sistemas reproductivos en especies de Melastomataceae en la Gran sabana (Estado Bolívar, Venezuela). Acta Botanica Venezuelica 31: 387-408.

Infostat. 2009. Infostat for Windows: base system user's guide, release 9.0. Universidad Nacional de Córdoba, Córdoba, Argentina.

Kerns, C.A. \& Inouye, D.W. 1993. Techniques for pollination biologists. Colorado University Press. Colorado.

Jürgens, A., Witt, T. \& Gottsberger, G. 2002. Pollen grain numbers, ovule numbers and pollen-ovule ratios in Caryophylloideae: correlation with breeding system, pollination, life form, style number, and sexual system. Sexual Plant Reproduction 14: 279-289. http://dx.doi.org/10.1007/ s00497-001-0124-2

Jürgens, A., Witt, T. \& Gottsberger, G. 2012. Pollen grain size variation in Caryophylloideae: a mixed strategy for pollen deposition along styles with long stigmatic areas? Plant Systematics and Evolution 298: 9-24. http://dx.doi.org/10.1007/s00606-011-0518-z

Lehnebach, C. \& Riveros, M. 2003. Pollination biology of the Chilean endemic orchid Chloraea lamellata. Biodiversity and Conservation 12: 1741-1751. http://dx.doi.org/10.1023/A:1023666800948

Lindsey, A.H. 1982. Floral phenology patterns and breeding systems in Thaspium and Zizia (Apiaceae). Systematic Botany 7: 1-12. http:// dx.doi.org/10.2307/2418648

López, J., Rodríguez-Riaño, T., Ortega-Olivencia, A., Devesa, J.A. \& Ruiz, T. 1999. Pollination mechanisms and pollen-ovule ratios in some Genisteae from Southwestern Europe. Plant Systematics and Evolution 216: 23-47. http://dx.doi.org/10.1007/BF00985099

Medan, D. 2003. Reproductive Biology of the Andean Shrub Discaia nana (Rhamnaceae). Plant Biology 5: 94-102. http://dx.doi.org/10.1055/ s-2003-37980

Ortega Olivencia, A. \& Devesa Alcaraz, J.A. 1993. Sexual reproduction in some Scrophularia species (Scrophulariaceae) from the Iberian Peninsula and the Balearic Islands. Plant Systematics and Evolution 184: 159-174. http://dx.doi.org/10.1007/BF00937433

Ortega Olivencia, A., Ramos, S., Rodríguez, T. \& Devesa Alcaraz, J.A. 1997. Floral biometry, floral rewards and pollen-ovule ratios in some Vicia from Extremadura, Spain. Edinburgh Journal of Botany 54: 39-53. http://dx.doi.org/10.1017/S0960428600003851

Pijl, L van der. 1954. Xylocopa and flowers in the tropics. I. Proceedings of the Koninklijke Nederlandse Akademie van Wetenschappen C 57: 413-423.

Plitmann, U. \& Levin, D.A. 1990. Breeding systems in Polemoniaceae. Plant Systematics and Evolution 170: 205-214. http://dx.doi.org/10.1007/ BF00937704 
Preston, R.E. 1986. Pollen-ovule ratios in the Cruciferae. American Journal of Botany 73: 1732-1740. http://dx.doi.org/10.2307/2444239

Roitman, G.G. \& Medán, D. 1994. La autogamia predomina en pastizales húmedos de la depresión del Salado, provincia de Buenos Aries. In: VI Congreso Latinoamericano de Botánica. Asociación Latinoamericana de Botánica. Libro de resúmenes: 594. Mar del Plata.

Schoen, D.J. 1977. Morphological, phenological, and pollen-distribution evidence of autogamy and xenogamy in Gilia achilleifolia (Polemoniaceae). Systematic Botany 2: 280-286. http://dx.doi.org/10.2307/2418460

Small, E. 1988. Pollen-ovule patterns in tribe Trifolieae. Plant Systematics and Evolution 160: 195-205. http://dx.doi.org/10.1007/BF00936047

Spira, T.P. 1980. Floral parameters, breeding system and pollinator type in Trichostema (Labiatae). American Journal of Botany 67: 278-284. http:// dx.doi.org/10.2307/2442337

Weller, S.G., Sakai, A.K., Rankin, A.E., Golonka, A., Kutcher, B. \& Ashby, K.E. 1998. Dioecy and the evolution of pollination systems in Schiedea and Alsinidendron (Caryophyllaceae: Alsinoideae) in the Hawaiian islands. American Journal of Botany 85: 1377-1388. http://dx.doi. org $/ 10.2307 / 2446396$

Wild, J.D., Mayer, E. \& Gottsberger, G. 2003. Pollination and reproduction of Tussilago farfara (Asteraceae). Botanische Jahrbücher für Systematik 124: 273-285. http://dx.doi.org/10.1127/0006-8152/2003/0124-0273

Wyatt, R. 1984. Evolution of self-pollination in granite outcrop species of Arenaria Caryophyllaceae). III. Reproductive effort and pollen-ovule ratios. Systematic Botany 9: 432-440. http://dx.doi.org/10.2307/2418792

Wyatt, R., Broyles, S.B. \& Lipow, S.R. 2000. Pollen-ovule ratios in milkweeds Asclepiadaceae): an exception that probes the rule. Systematic Botany 25: 171-180. http://dx.doi.org/10.2307/2666636

Associate Editor: Javier Fuertes Received: 07-VI-2013 Accepted: 12-X-2014 